\title{
Leiomyosarcoma and Endometrial Stromal Sarcoma pT3 TNM Finding v7
}

National Cancer Institute

\section{Source}

National Cancer Institute. Leiomyosarcoma and Endometrial Stromal Sarcoma pT3 TNM

Finding V7. NCI Thesaurus. Code C89592.

Tumor infiltrates abdominal tissues. (from AJCC 7th Ed.) 